\title{
Growth inhibition of Walker carcinosarcoma 256 with alcoholic extract of green tea leaves (Camellia sinensis) ${ }^{1}$
}

\author{
Inibição do crescimento do carcinossarcoma 256 de Walker pelo \\ extrato alcoólico de folhas de chá verde (Camellia sinensis)
}

\author{
Mauriclécio Franco Ponte', Thiago Sousa e Silva Targino", Matheus Alves de Lima Mota", José Saul Peixoto Landim", Thyciana \\ Rodrigues Ribeiro"II, Fabiana Pereira Soares ${ }^{\mathrm{IV}}$, Márcio Roberto Pinho Pereirav ${ }^{\mathrm{V}}$, Sônia Leite da Silvav, Silvia Fernandes Ribeiro \\ da Silva ${ }^{\text {II }}$ \\ ${ }^{I}$ Graduate student, School of Pharmacy, UNIFOR, Fortaleza-CE, Brazil. Involved with technical procedures, analysis and interpretation of data, \\ manuscript writing.

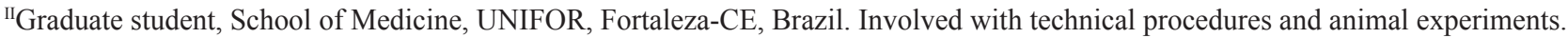 \\ IIIMaster, Volunteer Faculty, Federal University of Ceara, Brazil. Compiled the results and statistical analysis.

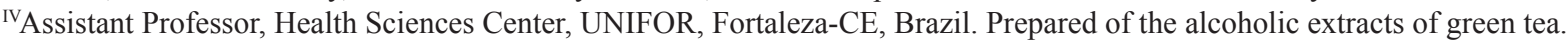 \\ ${ }^{v} \mathrm{PhD}$, Assistant Professor, Health Sciences Center, UNIFOR, Fortaleza-CE, Brazil. Supervised all phases of the study, interpretation of data and critical \\ revision. \\ ${ }^{\mathrm{V}} \mathrm{PhD}$, Assistant Professor, Health Sciences Center, UNIFOR, Fortaleza-CE, Brazil. Main author, responsible for conception, design, intellectual and \\ scientific content of the study, critical revision.
}

\begin{abstract}
PURPOSE: To evaluate the antitumor activity of alcoholic extracts of green tea (Camella sinensis). METHODS: Four groups of six Wistar rats were inoculated intramuscularly with $10^{6}$ Walker tumor cells $/ \mathrm{mL}$. During 10 days, the animals received by gavage either $0.9 \%$ saline solution (Group I; negative control), solution containing $20 \mathrm{mg} / \mathrm{Kg}$ of tamoxifen (Group II; positive control), solution containing $0.07 \mathrm{~g} / \mathrm{Kg}$ alcoholic extract of C. sinensis (Group III), or solution containing $0.14 \mathrm{~g} / \mathrm{Kg}$ alcoholic extract of $C$. sinensis (Group IV). Following euthanasia on the tenth day, the tumor, liver, kidneys and spleen were excised and weighed, and tumor volume and tumor growth inhibition were quantified.
\end{abstract}

RESULTS: The average weight of the animals was greater in Group IV than in Group II ( $\mathrm{p}=0.0107)$. Tumor weight was smaller in Group IV than in Group I ( $\mathrm{p}=0.0062)$, but did not differ from Group II. Tumor volume was smaller in Groups II and IV than in Group I ( $\mathrm{p}=0.0131)$. Tumor growth inhibition was observed in Groups II $(44.67 \% \pm 32.47)$, III $(16.83 \% \pm 53.02)$ and IV $(66.4 \% \pm 25.82)$ $(\mathrm{p}>0.05)$. The groups did not differ with regard to the weight of the excised organs.

CONCLUSION: Alcoholic extracts of green tea have antitumor activity.

Key words: Camellia sinensis. Catechin. Carcinoma 256, Walker. Rats.

\section{RESUMO}

OBJETIVO: Avaliar a atividade antitumoral do extrato alcoólico do chá verde (C. sinensis).

MÉTODOS: Quatro grupos de seis ratos Wistar foram inoculados com $1 \times 10^{6}$ células $/ \mathrm{mL}$ do tumor de Walker por via intramuscular. Os grupos foram tratados durante 10 dias, por gavagem, com salina $0,9 \%$ (Grupo I, controle negativo), $20 \mathrm{mg} / \mathrm{Kg}$ de tamoxifeno (Grupo II, controle positivo) e extrato alcoólico de C. sinensis nas doses de $0,07 \mathrm{~g} / \mathrm{Kg}$ (Grupo III) ou 0,14 g/Kg (Grupo IV). O volume e a inibição do crescimento tumoral foram calculados.

RESULTADOS: A média dos pesos dos animais foi maior no Grupo IV do que no Grupo II ( $\mathrm{p}=0,0107$ ). O peso tumoral do Grupo IV foi menor do que o Grupo I ( $\mathrm{p}=0,0062)$, mas não houve diferença quando comparado ao Grupo II. O volume tumoral foi menor nos grupos II e IV quando comparados ao Grupo I ( $\mathrm{p}=0,0131$ ). Inibição tumoral foi observada nos Grupos II $=44,67 \pm 32,47$, III $=16,83 \pm 53,02$ e $\mathrm{IV}=66,4 \pm 25,82$ ( $>>0,05)$. Não houve diferença no peso dos órgãos entre os grupos.

CONCLUSÃO: O extrato alcoólico do chá verde possui ação antitumoral.

Descritores: Camellia sinensis. Catequina. Carcinoma 256 de Walker. Ratos. 


\section{Introduction}

After water, tea is the most highly consumed nonalcoholic beverage in the world ${ }^{1}$. A considerable part of this tea is prepared with leaves of the shrub Camellia sinensis in the form of green tea $(\sim 20 \%)$, oolong $(\sim 2 \%)$ or black tea $(\sim 78 \%)^{2}$.

The pharmacological properties of the compounds found in green tea have been the object of much study. Among these compounds are flavonoids of rather unique chemical structure and biological functions ${ }^{3,4}$. The most important flavonoids in green tea are monomeric catechins, namely epigallocatechin (EGC), epigallocatechin 3-gallate (EGCG), epicatechin (EC) and epicatechin 3-gallate (ECG). EGCG accounts for 59\% of total catechins, followed by EGC (19\%), ECG (13.6\%) and EC $(6.4 \%)^{5}$.

Since ancient times green tea has been considered a healthy and medicinal beverage capable of reducing the risk of several diseases, probably due to the presence of catechins. In fact, catechins have been shown to have antioxidant, anti-inflammatory, immunomodulating, antilipidemic, antibiotic, antiangiogenic and anticarcinogenic effects ${ }^{5,6}$.

Developed in 1928 by George Walker, the experimental tumor model 'Walker carcinosarcoma 256' has been extensively used in studies of the physiopathological mechanisms of carcinogenesis and in preclinical testing of new antitumor drugs, with extrapolation of results to human physiology ${ }^{7}$. According to Moraes et al. ${ }^{8}$, the tumor take rate is $100 \%$ in male Wistar rats inoculated intramuscularly with $10^{6}$ cells $/ \mathrm{mL}$.

In view of the widely documented biological properties of green tea, the purpose of the present study was to evaluate the antitumor activity of extracts of Camellia sinensis in male Wistar rats inoculated with Walker carcinosarcoma 256.

\section{Methods}

The study was previously approved by the Institutional Animal Care and Use Committee of University of Fortaleza (\#008/2009). Twenty-four male Wistar rats weighing 150-200 grams were used in the study. The animals were supplied by the experimental animal facility of the Health Sciences Center at University of Fortaleza, distributed into four groups of six animals each and accommodated in cages $(30 \times 17 \times 15 \mathrm{~cm})$ in a controlled environment (circadian cycle, $25^{\circ} \mathrm{C}$, water and Fri-Ribe ${ }^{\circledR}$ rat chow ad libitum throughout the experiment).
Preparation of alcoholic extract of leaves of Camellia sinensis

Leaves $(95 \mathrm{~g})$ of $C$. sinensis (Amor à Vida Produtos Naturais ${ }^{\circledR}$ ) were ground and macerated with $400 \mathrm{~mL}$ absolute ethanol at room temperature for five days. The extract was then filtered and the maceration process was repeated with the residue. The solvent of the extract was evaporated by heating in a water bath at $60^{\circ} \mathrm{C}$ until obtaining a final volume of $25 \mathrm{~mL}$. During the entire procedure, the extract was shielded from direct light exposure. Finally, $70 \mathrm{~mL}$ distilled water was added to the extract to make $95 \mathrm{~mL}$ solution at a drug concentration of $1 \mathrm{~g} / \mathrm{mL}$. The fraction was stored in an amber vial at $4^{\circ} \mathrm{C}$ until the time of use.

The highest dose of extract administered in the study $(0.14 \mathrm{~g} / \mathrm{kg})$ was based on the consumption of 1 liter of green tea (prepared with $10 \mathrm{~g}$ C. sinensis leaves) by an individual weighing $70 \mathrm{Kg}$.

\section{Inoculation of Walker carcinosarcoma 256}

The inoculation of tumor cells was performed as described by Silva et al. ${ }^{9}$. Following sedation with $20 \%$ chloral hydrate, $1 \mathrm{~mL}$ suspension containing $10^{6}$ tumor cells was injected subcutaneously in the right axillary region using an insulin syringe.

\section{Experimental protocol}

The experiment lasted 10 days. On the first day, the 24 animals were weighed, distributed in four groups of six animals each, and inoculated with tumor cells.

Every day until the ninth day, the animals received by gavage either $1 \mathrm{~mL} 0.9 \%$ saline solution (Group I; negative control), $1 \mathrm{~mL}$ solution containing $20 \mathrm{mg} / \mathrm{Kg}$ of tamoxifen (Group II; positive control), $1 \mathrm{~mL}$ solution containing $0.07 \mathrm{~g} / \mathrm{Kg}$ alcoholic extract of $C$. sinensis (Group III), or $1 \mathrm{~mL}$ solution containing 0.14 $\mathrm{g} / \mathrm{Kg}$ alcoholic extract of $C$. sinensis (Group IV).

The animals were weighed every other day throughout the experiment to collect data for growth curves. On the tenth day of the experiment, the animals were anesthetized with chloral hydrate and euthanized by cervical dislocation. Finally, the tumor, liver, kidneys and spleen were excised and weighed.

\section{Tumor measurement}

The excised tumors were measured with a caliper. The largest and smallest diameter were registered and tumor volume was calculated using Steel's formula:

$$
\mathrm{V}\left(\mathrm{cm}^{3}\right)=\mathrm{D} \times \mathrm{d}^{2} / 2
$$

where $\mathrm{V}$ is tumor volume, $\mathrm{D}$ is the greatest diameter and $\mathrm{d}$ is the smallest diameter. 


\section{Inhibition of tumor growth}

The inhibition of tumor growth was calculated based on mean tumor weight (MTW) in mg on the tenth day of the experiment ${ }^{10}$.

\section{$\underline{\mathrm{T} / \mathrm{C} \%=\mathrm{MTW} \text { (treatment group) } \times 100}$ MTW (control group)}

The percentage of inhibition is $100-\mathrm{T} / \mathrm{C} \%$.

\section{Statistical analysis}

The data were submitted to variance analysis followed by the Student-Newman-Keuls test, using the software GraphPad Prism. Mean values \pm standard deviation for each group were compared. The level of statistical significance was set at $5 \%$ $(\mathrm{p}<0.05)$.

\section{Results}

Figure 1 shows the evolution in average weight of the four groups throughout the experiment. On the sixth day, the average weight of the animals was higher in Group IV than in Groups I and II $(\mathrm{p}=0.0107)$. Between the seventh and the tenth day, the average weight of the animals was greater in Group IV than in Groups I, II and III, but the difference was only statistically significant between Group IV and Group II (Table 1). The animals in Groups I and III weighed more than the animals in Group II, but the difference was not statistically significant $(\mathrm{p}>0.05)$.

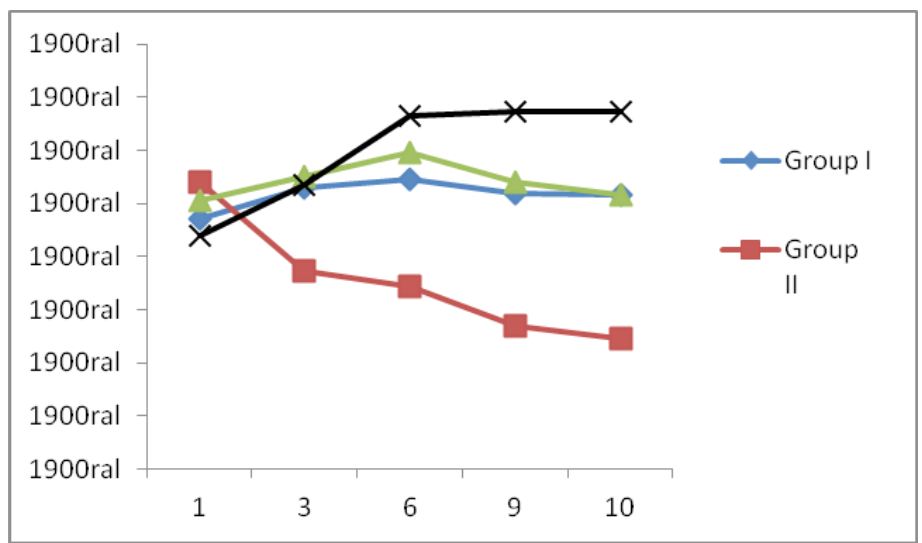

FIGURE 1 - Evolution in average weight of 24 male Wistar rats treated with either $1 \mathrm{~mL} 0.9 \%$ saline solution (Group I; negative control), $1 \mathrm{~mL}$ solution containing $20 \mathrm{mg} / \mathrm{Kg}$ of tamoxifen (Group II; positive control), 1 $\mathrm{mL}$ solution containing $0.07 \mathrm{~g} / \mathrm{Kg}$ alcoholic extract of $C$. sinensis (Group III), or $1 \mathrm{~mL}$ solution containing $0.14 \mathrm{~g} / \mathrm{Kg}$ alcoholic extract of $C$. sinensis (Group IV).
TABLE 1 - Average weight of 24 male Wistar rats treated with either $1 \mathrm{~mL} 0.9 \%$ saline solution (Group I; negative control), $1 \mathrm{~mL}$ solution containing $20 \mathrm{mg} / \mathrm{Kg}$ of tamoxifen (Group II; positive control), $1 \mathrm{~mL}$ solution containing $0.07 \mathrm{~g} / \mathrm{Kg}$ alcoholic extract of $C$. sinensis (Group III), or $1 \mathrm{~mL}$ solution containing 0.14 $\mathrm{g} / \mathrm{Kg}$ alcoholic extract of $C$. sinensis (Group IV).

\begin{tabular}{cccccc}
\hline Days & Group I & Group II & Group III & Group IV & p \\
\hline \hline 6 & $233.3^{*}$ & $237.2^{*}$ & 249.8 & $253.3^{*}$ & 0.0107 \\
7 & 248.0 & $235.5^{*}$ & 252.2 & $255.0^{*}$ & 0.0298 \\
8 & 245.2 & $235.3^{*}$ & 251.0 & $253.3^{*}$ & 0.0477 \\
9 & 246.0 & $233.5^{*}$ & 247.0 & $253.7^{*}$ & 0.0461 \\
10 & 245.8 & $232.2^{*}$ & 245.8 & $253.7^{*}$ & 0.0645 \\
\hline
\end{tabular}

On the tenth day of the experiment, tumor weight was significantly lower in Groups II (5.728g) and IV (3.804g) than in Groups I (12.78g) and III (10.54g) (Figure 2, $\mathrm{p}=0.0062)$.

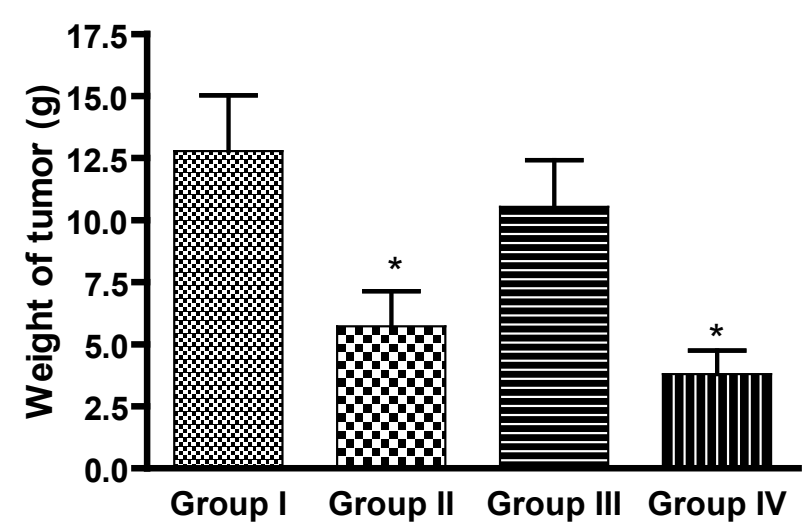

FIGURE 2 - Weight of Walker carcinosarcoma 256 inoculated in 24 Wistar rats treated with either $1 \mathrm{~mL} 0.9 \%$ saline solution (Group I; negative control), $1 \mathrm{~mL}$ solution containing $20 \mathrm{mg} / \mathrm{Kg}$ of tamoxifen (Group II; positive control), $1 \mathrm{~mL}$ solution containing $0.07 \mathrm{~g} / \mathrm{Kg}$ alcoholic extract of C. sinensis (Group III), or $1 \mathrm{~mL}$ solution containing $0.14 \mathrm{~g} / \mathrm{Kg}$ alcoholic extract of $C$. sinensis (Group IV).

The four groups did not differ significantly with regard to the weight of the spleen, liver or kidneys, although the spleen tended to weigh less in the animals of Group II ( $p>0.05$ ).

As shown in Figure 3, tumor volume was smaller in Groups II and IV than in Group I ( $\mathrm{p}=0.0131)$. Groups I and III did not differ significantly ( $>0.05$ ). 


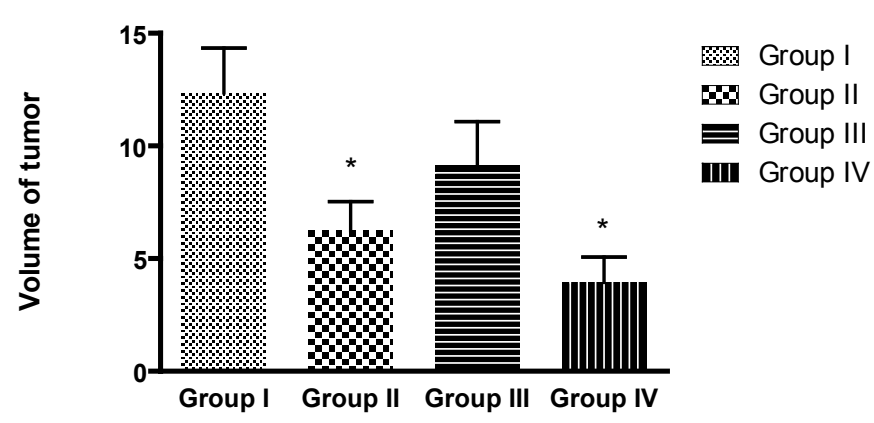

FIGURE 3 - Volume of Walker carcinosarcoma 256 in 24 Wistar rats treated with either $1 \mathrm{~mL} 0.9 \%$ saline solution (Group I; negative control), $1 \mathrm{~mL}$ solution containing $20 \mathrm{mg} / \mathrm{Kg}$ of tamoxifen (Group II; positive control), $1 \mathrm{~mL}$ solution containing $0.07 \mathrm{~g} / \mathrm{Kg}$ alcoholic extract of $C$. sinensis (Group III), or $1 \mathrm{~mL}$ solution containing $0.14 \mathrm{~g} / \mathrm{Kg}$ alcoholic extract of C. sinensis (Group IV).

Tumor growth inhibition was observed in Groups II $(44.67 \% \pm 32.47)$, III $(16.83 \% \pm 53.02)$ and IV $(66.4 \% \pm 25.82)$. Although inhibition was greater in Group IV than in Groups II and III, the difference was not statistically significant $(\mathrm{p}>0.05)$.

\section{Discussion}

EGCG, the most important catechin in green tea, is known to protect several organs, such as the bowels, lungs, liver, prostate and breasts, against chemical carcinogens ${ }^{11-13}$. To our knowledge, no studies on the relation between green tea consumption and cancer prevention have been published in Brazil so far. The present study on the effect of green tea on tumor growth in a murine cancer model is intended to encourage further research and discussion.

In our study, EGCG was not used in isolation, but the animals were treated with an alcoholic extract of the leaves of $C$. sinensis containing a combination of catechins. Nevertheless, the observed tumor growth inhibition in animals treated with extract at $0.07 \mathrm{~g} / \mathrm{Kg}$ (Group III) and $0.14 \mathrm{~g} / \mathrm{Kg}$ (Group IV) matches the results of several other studies evaluating the antitumor activity of green tea extracts. Tumor weight was greater, though not significantly, in Group IV than in Groups II and III, whereas it was significantly smaller in Group IV than in Group I (negative control). Despite the absence of a statistically significant difference, the combination of these two findings suggests the antitumor effect of the extract was dose-dependent.

The present study was not designed to investigate the mechanism responsible for inhibiting the growth of Walker carcinosarcoma 256, but studies using EGCG alone have shown that the compound induces apoptosis in malignant cells due to its oxidative properties. According to Zou et al. ${ }^{14}$, high concentrations of EGCG $(100-200 \mu \mathrm{M})$ appear to be associated with intracellular production of free radicals, whereas low concentrations $(10 \mu \mathrm{M})$ are believed to have antioxidant effects. In addition, EGCG timeand dose-dependently inhibits tumor cell molecules regulating the cell cycle, such as nuclear factor kappa B (NFKB) and activator protein 1 (AP-1), thereby compromising the continuity of the cell cycle and favoring apoptosis ${ }^{15}$.

In a study evaluating the toxicity of different concentrations $(0.3 \%, 1.25 \%, 5 \%)$ of catechins in male rats, the weight of the thymus, lungs, heart, spleen, liver, thyroid gland and pituitary gland was significantly reduced in animals treated with the highest concentration of catechins ${ }^{16}$. In contrast, in our experiment the average weight of the spleen, liver and kidneys was similar for rats in the treatment groups (alcoholic extract of leaves of $C$. Sinensis at $0.07 \mathrm{~g} / \mathrm{Kg}$ and $0.14 \mathrm{~g} / \mathrm{Kg}$ ) and rats in the negative control group.

Green tea is an important antioxidant in human diet, with encouraging perspectives as a potential protector against disease ${ }^{5}$. In this study, the dose of $0.14 \mathrm{~g} / \mathrm{Kg}$ (Group IV) was associated with protective weight loss when compared to administration of tamoxifen. Some authors believe that differences between the effects of green tea observed in humans and in animal models are due to the use of higher catechin concentrations in the latter ${ }^{17}$. However, the dose of extract administered in this study $(0.14 \mathrm{~g} / \mathrm{kg})$ was based on the consumption of 1 liter of green tea (prepared with $10 \mathrm{~g}$ C. sinensis leaves) by an individual weighing $70 \mathrm{Kg}$. Further research is necessary to determine whether the observed antitumor effect is dose-dependent and whether it may be extrapolated to other types of tumors.

\section{Conclusion}

An alcoholic extract of Camellia sinensis at $0.14 \mathrm{~g} / \mathrm{kg}$ significantly inhibited the growth of Walker carcinosarcoma 256.

\section{References}

1. Senger AE, Schaeanke CHA, Gottieb MGV. Chá verde (Camellia sinensis) e suas propriedades funcionais nas doenças crônicas não transmissíveis. Sci Med. 2010;20(4):292-300.

2. Kang H, Rha SY, Oh KW, Nam CM. Green tea consumption and stomach cancer risk: a meta-analysis. Epidemiol Health. 2010;32:18.

3. Khan N, Mukhtar H. Tea polyphenols for health promotion. Life Sci. 2007;81(7):519-33.

4. Freitas HCP, Navarro F. O chá verde induz o emagrecimento e auxilia no tratamento da obesidade e sua comorbidades. Rev Bras Obes Nut Emagrec. 2007;1(2):16-26.

5. Cabrera C, Gimenéz R. Beneficial effects of Green tea-a review. J Am Cool Nutr. 2006;25(2):79-99. 
6. Takami S, Imai T, Hasumura M, Cho YM, Onose J, Hirose M. Evaluation of toxicity of green tea catechins with 90-day dietary administration to F344 rats. Food Chem Toxicol. 2008;46(6):22249.

7. Brito NMB, Brito MVH, Carvalho RKV, Matos LTMB, Lobato RC, Corrêa SC, Brito RB. The effect of copaiba balsam on Walker 256 carcinoma inoculated into the vagina and uterine cervix of female rats. Acta Cir Bras. 2010;25(2):176-80.

8. Moraes SP, Cunha A, Reis Neto JA, Barbosa H, Roncolatto CAP, Duarte, RF. Modelo experimental de tumor de Walker. Acta Cir Bras. 2000;15(4):237-42.

9. Silva SL, Silva SFR, Farias IN, Mota RS, Moraes ME, Campos HH, Ferreira FV, Moraes Filho MO. Um novo modelo de isolamento do tumor de Walker utilizando o gradiente de Ficoll-Hypaque. Acta Cir Bras. 2006;21(2):101-5.

10. Eng CP, Sehgal SN, Vézina C. Activity of rapamycin (AY-22, 989) against transplanted tumors. J Antibiot. 1984;37:1231-7.

11. Mehrabian S. The study of antioxidant and anticarcinogenic green tea and black tea. Pak J Biol Sci. 2007;10(6):989-91.

12. Yang CS, Prabhu S, Landau J. Prevention of carcinogenesis by tea polyphenols. Drug Metab Rev. 2001;33(3-4):237-53.

13. Crespy V, Williamson G. A Review of the health effects of green tea catechins in vivo animal models. J Nutr. 2004;134:3431S-40S.

14. Zou C, Liu H, Feugang JM, Hao Z, Chow HH, Garcia F. Green tea compound in chemoprevention of cervical cancer. Int J Gynecol Cancer. 2010;20(04):617-24.

15. Chen L, Zhang HY. Cancer preventive mechanisms of the green tea polyphenol (-)-epigallocatechin-3-gallate. Molecules. 2007;12(5):946-57.

16. Yang CS, Wang X, Lu G, Picinich SC. Cancer prevention by tea: animal studies, molecular mechanisms and human relevance. Nat Rev Cancer. 2009;9(6):429-39.

17. Demeule M, Michaud-Levesque J, Annabi B, Gingras D, Boivin D, Jodoin J, Lamy S, Bertrand Y, Béliveau R. Green tea catechins as novel antitumor and antiangiogenic compounds. Curr Med Chem Anticancer Agents. 2002;2:441-63

\section{Correspondence:}

Silvia Fernandes Ribeiro da Silva

Universidade de Fortaleza

Avenida Washington Soares, 1321/Bloco C

60811-905 Fortaleza - Ceará Brasil

silviafernandes@unifor.br

Received: April 10, 2012

Review: June 12, 2012

Accepted: July 11, 2012

Conflict of interest: none

Financial source: none

${ }^{1}$ Research performed at Laboratory of Immunology, Health Sciences Center, University of Fortaleza (UNIFOR), Ceara, Brazil. 